\title{
Dyskeratosis congenita: three additional families show linkage to a locus in $\mathrm{Xq} 28$
}

\author{
Reynir Arngrimsson, Inderjeet Dokal, Lucio Luzzatto, J Michael Connor
}

\begin{abstract}
Dyskeratosis congenita (DC) is a rare inherited disorder with most families being of the $X$ linked recessive type. We describe three families which show linkage to the marker DXS52 on Xq28. The combined maximum lod score was 2.00 at zero recombination. This is further evidence that the $X$ linked DC gene is located at Xq28 and brings the reported maximum lod score for DC and DXS52 to 5.33 at zero recombination fraction, with a supporting recombination fraction interval of $0 \cdot 00-0 \cdot 10$.

( $f$ Med Genet 1993;30:618-19)
\end{abstract}

Dyskeratosis congenita is a rare inherited disorder, characterised by reticulate skin hyperpigmentation, nail dystrophy, lacrimal duct obstruction, and leucoplakia of the mucous membranes. More serious features are bone marrow hypofunction, pancytopenia, and a predisposition to malignancy.

Manifestation is usually in childhood with serious complications starting in mid teens with a mean age of death at 23.6 years (range 8 to 50 years). Over 100 cases, mostly males (M/ $F$ ratio 8:1), have now been reported. About half of these are sporadic and half familial. ${ }^{1}$

$\mathrm{X}$ linked recessive inheritance is supported by pedigree pattern in several large families ${ }^{23}$ but reports of five affected females in one family with a milder and less typical phenotype $^{4}$ and male to male transmission ${ }^{5}$ suggest genetic heterogeneity.

Linkage analysis in one large pedigree using multiple $\mathrm{X}$ chromosomal DNA polymorphisms assigned the locus to $\mathrm{Xq} 28 .^{6}$ This paper reports three further families which show linkage to this same region of the $X$ chromosome.

\section{Subjects and methods}

PATIENTS (FIG 1)

Family 1 has been described in detail by Dokal et al. ${ }^{7}$ The proband first presented with symptoms of DC at the age of 29 years. His younger brother was diagnosed when he was 26 years old, while being assessed as a potential bone marrow donor.

Patient 3 is a nephew of patients 1 and 2 . He was investigated at the age of 12 years and the diagnosis of DC was made. An older half sister of the proband had two sons, who showed no signs of DC on clinical examination and laboratory investigation. Their phenotype was assigned as normal.

Family 2 is a South African family and has been described in detail by Jacobs et al. ${ }^{8}$ Three boys and their maternal grandfather were diagnosed as having DC. The grandfather and two of the affected boys were dead, leaving one affected boy, his mother, and two normal brothers available for this linkage study.

In family 3 the proband, of British origin, was diagnosed as having DC. His uncle had died earlier of pneumonia and was noted to have nail dystrophy. The proband, his normal brother, and mother, who is an obligate carrier, were available for linkage analysis.

\section{DNA STUDIES}

DNA was extracted from leucocytes using standard methods and 5 to $10 \mu \mathrm{g}$ of DNA were digested overnight using TaqI enzyme (NBL) under conditions defined by the manfacturer. Restriction fragments were separated in $0.8 \%$ agarose gels and transferred by Southern blotting 9 to Hybond-N (Amersham).

The probe used was DXS52 (St14.1), ${ }^{10}$ which is multiallelic with a PIC value of 0.77 , and is a reference marker for $\mathrm{Xq} 28$. The probe

\author{
Duncan Guthrie \\ Institute of Medical \\ Genetics, Yorkhill, \\ Glasgow G3 8SJ, UK. \\ R Arngrimsson \\ $\mathrm{J} M$ Connor \\ Department of \\ Haematology, Royal \\ Postgraduate Medical \\ School and \\ Hammersmith \\ Hospital, Du Cane \\ Road, London W12 \\ ONN, UK. \\ I Dokal \\ L Luzzatto \\ Correspondence to Professor \\ Connor. \\ Received 5 January 1993. \\ Revised version accepted \\ 22 February 1993.
}

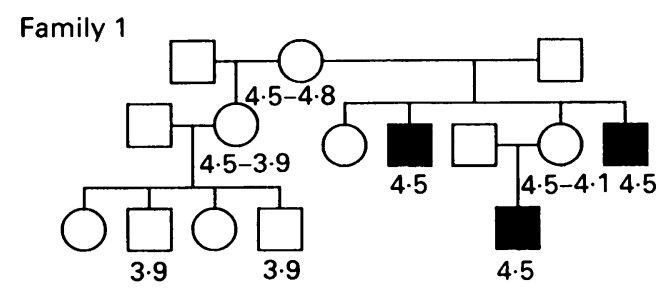

Family 3
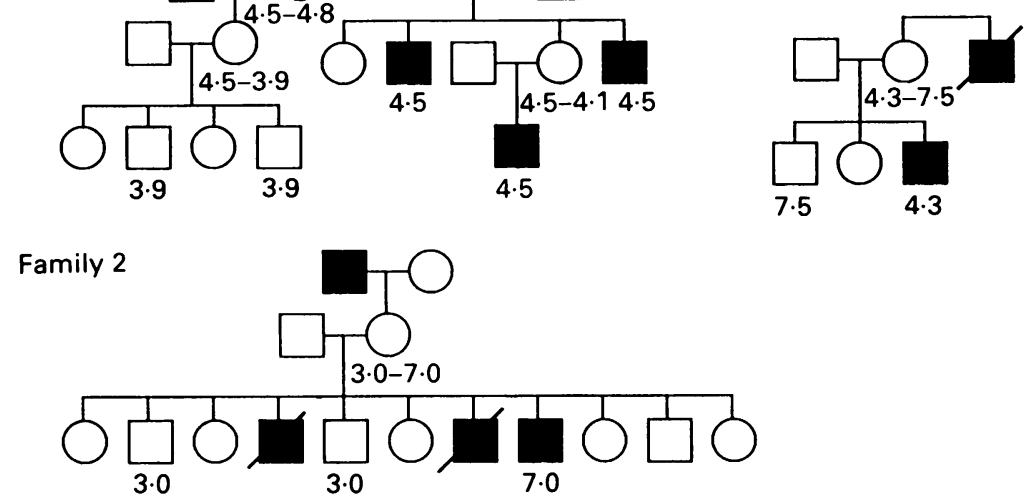

Pedigrees of the three dyskeratosis congenita families studied. DXS52 genotypes are indicated. 
Table 1 Lod scores for dyskeratosis congenita and DXS52.

\begin{tabular}{lllllll}
\hline & \multicolumn{5}{c}{ Recombination fraction } \\
\cline { 2 - 7 } Family & 0.00 & 0.05 & 0.10 & 0.20 & 0.30 & 0.40 \\
\hline 1 & 1.10 & 0.98 & 0.84 & 0.54 & 0.34 & 0.14 \\
2 & 0.60 & 0.55 & 0.46 & 0.32 & 0.17 & 0.05 \\
3 & 0.30 & 0.26 & 0.22 & 0.13 & 0.06 & 0.02 \\
Total & 2.00 & 1.79 & 1.52 & 0.99 & 0.57 & 0.21 \\
\hline
\end{tabular}

Table 2 Combined lod scores from this study and that of Connor et al between dyskeratosis congenita and DXS52.

\begin{tabular}{|c|c|c|c|c|c|c|}
\hline \multirow[b]{2}{*}{ Study } & \multicolumn{6}{|c|}{ Recombination fraction } \\
\hline & 0.00 & 0.05 & $0 \cdot 10$ & $0 \cdot 20$ & $0 \cdot 30$ & $0 \cdot 40$ \\
\hline $\begin{array}{l}\text { Present } \\
\text { Connor et al }\end{array}$ & $\begin{array}{l}2.00 \\
3.33\end{array}$ & $\begin{array}{l}1 \cdot 79 \\
3.06\end{array}$ & $\begin{array}{l}1 \cdot 52 \\
2 \cdot 77\end{array}$ & $\begin{array}{l}0.99 \\
2 \cdot 14\end{array}$ & $\begin{array}{l}0.57 \\
1.43\end{array}$ & $\begin{array}{l}0.21 \\
0.70\end{array}$ \\
\hline Total & $5 \cdot 33$ & $4 \cdot 85$ & $4 \cdot 29$ & $3 \cdot 13$ & $2 \cdot 00$ & 0.91 \\
\hline
\end{tabular}

was labelled with ${ }^{32} \mathrm{P}$ either by nick translation $^{11}$ or by oligonucleotide labelling. ${ }^{12}$ Hybridisation was performed overnight at $42^{\circ} \mathrm{C}$ in hybridisation buffer as follows: $50 \%$ formamide, $1 \times$ Denhardt's, $5 \times$ SSC, $20 \mathrm{mmol} / 1 \mathrm{NaH}_{2} \mathrm{PO}_{4}, \mathrm{pH} 6 \cdot 8,0 \cdot 1 \mathrm{mg} / \mathrm{ml}$ heat denatured salmon sperm DNA, $0.02 \mathrm{mg} / \mathrm{ml}$ poly(A), and $10 \%$ dextran sulphate. Non-specifically bound probe was removed by washing in $1 \times \mathrm{SSC}, 0.1 \%$ sodium dodecyl sulphate (SDS) followed by $0.5 \times$ SSC, $0.1 \%$ SDS, both at room temperature, and finally one or two washes in $0.1 \times \mathrm{SSC}, 0.1 \% \mathrm{SDS}$ at $65^{\circ} \mathrm{C}$. Bands were visualised by autoradiography for one to seven days at $-80^{\circ} \mathrm{C}$ using intensifying screens.

Lod scores were calculated using the computer program LIPED. ${ }^{13}$ In these calculations a disease allele frequency of 0.01 was used, and complete penetrance was assumed for hemizygous males. The supporting interval was estimated by finding the recombination fraction at the lod score which was one unit lower than the maximum lod score.

\section{Results}

Pairwise linkage analysis showed no recombination between the locus for DC and RFLPs identified by DXS52 in all three families. A combined maximum lod score of 2.00 was observed at zero recombination fraction (table 1).

These results bring the total lod score for DC and DXS52 to 5.33 at zero recombination (table 2). The supporting recombination interval is $0 \cdot 00-0 \cdot 10$.

\section{Discussion}

Linkage analysis in one large family using multiple $\mathrm{X}$ chromosomal DNA polymorphisms has previously assigned the gene for $\mathrm{X}$ linked recessive dyskeratosis congenita to $\mathrm{Xq} 28 .^{6}$ Another family showed cosegregation of DC and G6PD deficiency ${ }^{14}$ which also maps to Xq28. Only one recombination between DC and G6PD was observed among nine postpubertal males. This study was, however, limited as the assay only allowed the genotype of the females to be assigned on the basis of their offspring's phenotypes.

The present study supports tight linkage between DC and loci on Xq28 and raises the maximum lod score for DXS52 from 3.33 previously described ${ }^{6}$ to $5 \cdot 33$ (table 2 ). These results will allow further testing of other kindreds to identify genetic heterogeneity which has been suggested on the grounds of clinical and pedigree data.

The authors would like to thank Professor N Saxe, Department of Dermatology, Groote Schuur Hospital, Cape Town, Professor P Beighton, Department of Human Genetics, University of Cape Town, Dr D Oscier and Dr J Hows, Royal Postgraduate Medical School, Hammersmith Hospital, London, for providing clinical information on the families used in this study.

1 Davidson R, Connor JM. Dyskeratosis congenita. $\mathcal{f}$ Med Genet 1988;25:843-6.

2 Sirinavin C, Trowbridge AA. Dyskeratosis congenita: clinical features and genetic aspects. $\mathcal{f}$ Med Genet 1975;12:339-54.

3 Carter DM, Pan M, Gaynor A, McGuire J, Sibrack L. Psoralen-DNA cross-linking photoadducts in dyskeratosis congenita: delay in excision and promotion of sister chromatid exchange. $\mathcal{F}$ Invest Dermatol 1979;73:97-101.

4 Tchou PK, Kohn T. Dyskeratosis congenita: an autosomal dominant disorder. F Am Acad Dermatol 1982;6:1034-9.

5 Scoggins RB, Prescot KJ, Asher GH, Blaylock WK, Bright $\mathrm{RW}$. Dyskeratosis congenita with Fanconi-type anemia: investigation of immunologic and other defects. Clin Res 1971;19:409.

6 Connor JM, Gatherer D, Gray FC, Lindsay A, Pirrit LA, Affara NA. Assignment of the gene for dyskeratosis congenita to Xq28. Hum Genet 1986;72:348-51.

7 Dokal I, Bungey J, Williamson P, Oscier D, Hows J, Luzatto L. Dyskeratosis congenita fibroblasts are abnormal and have unbalanced chromosomal rearrangements. Blood 1992;80:3090-6.

8 Jacobs P, Saxe N, Gordon W, Nelson NN. Dyskeratosis congenita. Haematologic, cytogenetic and dermatologic studies. Scand f Haematol 1984;32:461-8.

9 Southern EM. Detection of specific sequences among DNA fragments separated by gel electrophoresis. $\mathcal{f} \mathrm{Mol} \mathrm{Biol}$ 1975;98:503-17.

10 Oberle I, Drayna D, Camerino G, White R, Mandel JL. The telomeric region of the human $X$ chromosome long arm: presence of a highly polymorphic DNA marker and analysis of recombination frequency. Proc Natl Acad Sci USA 1985;82:2824-8.

11 Rigby PWJ, Dieckmann M, Rhodes C, Berg P. Labelling DNA to high-specific activity by in vitro nick translation with DNA polymerase. $\mathcal{F}$ Mol Biol 1977;113:237-51.

12 Feinberg AP, Vogelstein B. A technique for radiolabeling DNA restriction endonuclease fragments to high specific activity. Anal Biochem 1983;132:613.

13 Ott J. Estimation of the recombination fraction in human pedigrees: efficient computation of the likelihood for human linkage studies. Am f Hum Genet 1974;26:588-97.

14 Gutman A, Frumkin A, Adam A, Bloch-Shtacher N, Rozenszajn LA. X-linked dyskeratosis congenita with pancytopenia. Arch Dermatol 1978;114:1667-71. 